\title{
Organizational Rewards and Performance of Health Centre IV Workers in Greater Mbarara District, Uganda
}

Johnson Atwiine ( $\square$ jatwiine@bds.bsu.ac.ug )

Bishop Stuart University https://orcid.org/0000-0001-7118-4757

Gershom Atukunda

Bishop Stuart University

Wycliffe Tumwesigye

Bishop Stuart University

Justus Asasira

Mbarara University of Science and Technology

Research

Keywords: Organizational rewards, Performance of Health Center IV Workers

Posted Date: October 6th, 2020

DOI: https://doi.org/10.21203/rs.3.rs-78693/v1

License: (c) (i) This work is licensed under a Creative Commons Attribution 4.0 International License.

Read Full License

Version of Record: A version of this preprint was published at Open Access Journal of Biogeneric Science and Research on March 19th, 2021. See the published version at https://doi.org/10.46718/JBGSR.2021.08.000189. 


\title{
Organizational Rewards and Performance of Health Centre IV workers in Greater Mbarara District, Uganda.
}

\author{
Johnson Atwiine ${ }^{a}$, Gershom Atukunda ${ }^{\text {b }}$, Wycliffe Tumwesigye ${ }^{c}$, Justus Asasira ${ }^{\mathrm{d}}$
}

Corresponding Authors' email:

ajatwiine@ bds.bsu.ac.ug or atwiinej20@gmail.com

dasasirajsts@gmail.com

\begin{abstract}
Purpose: The purpose of this paper is to study relationship between organizational rewards, and performance of Health Centre IV workers in greater Mbarara District.
\end{abstract}

Methods: This study used cross-sectional, explanatory and correlational approaches, and it utilised health center IV's workers' data that were collected by using a questionnaire survey from a sample of 200 health workers from 11 health centres from greater Mbarara district.

Findings: Results revealed that rewards, were significantly associated with health workers' performances. Contrary to previous thinking, organizational rewards and constructs do not significantly predict health workers' performance. Once health centre IV's have appropriate reward strategies for their health workers in health facilities, they are likely to work hard by meeting deadlines, being available at their work station and they would eventually enhance on job performance.

Research limitations/implications: This study focuses on rewards, and performance of health workers' in health centres iv in greater Mbarara and it is possible that these results are only applicable to the public health centres iv in greater Mbarara. More research is therefore needed to further understand the relationship between rewards, and performance of health workers in other sectors such as the private health sector and in other areas of the country like northern, central and eastern Uganda.

Practical implications: The results are important for health policy development and implementation, for example, in terms of primary health care and reporting lines for the health workers so as to enhance on their performance in public health sector.

Originality/value: As far as the authors are aware, no research has hitherto been undertaken that investigates the relationship between reward practices on health workers' performance in health centres IV in greater Mbarara district. Thus the results of this study will provide health practitioners with better insights in some reward practices that could be adopted by government/health practitioners so as to improve the performance of health centres IV workers.

Key words: Organizational rewards, Performance of Health Center IV Workers

Paper type: Research paper

Introduction 
The study reports the results of the study carried out to establish the association between organizational rewards and employee performance in health centre IV in greater Mbarara district. Many approaches have been developed and adopted worldwide to improve the employee's performance including salary enhancements, performance bonuses, and promotion and recognition strategies. The aim of all strategies is how to effectively motivate employees to maximise their performance. One common method of motivation is to tie rewards to employee performance which has been focused in this study.

The impact of rewards on employees' performance is well known phenomenon in the available literature of human resources. A large number of studies have verified that reward is a powerful tool to enhance employee behaviours leading to performance improvement. However, some other studies also observed the negative consequences of rewards such as an environment of favouritism, sexism and racism, nepotism and tribalism.

According to (Qureshi, Zaman, \& Shah, 2010) there are two basic types of rewards, financial and nonfinancial and both can be utilised positively to enhance performance behaviours of employees. Financial rewards mean pay-for-performance such as performance bonus, job promotion, commission, tips, salary etc. Non-financial rewards are non-monetary and it is a social recognition such as acknowledgment, certificate, and genuine appreciation etc. The non-financial rewards is also called non-material award (Neckermann \& Kosfeld, 2008).

Financial rewards like money is therefore important and powerful factor in motivating healthcare workers, it also a vital avenue for meeting the basic needs of healthcare workers such as housing and other costs like food. According to research surveys piloted in some nations, like North Vietnam (Dieleman, Cuong, \& Martineau, 2003), Mali (Dieleman \& Harnmeijer, 2006), Ghana (Adzei \& Atinga, 2012) and the UK(Adzei \& Atinga, 2012), the implication of basic salary in supporting the survival needs of workers beyond subsistence is a critical motivator. Hence, financial incentives are considered significant drivers for work morale and employee inspirations, which sustain higher levels of output.

Relatedly, other researchers argue that an increment in salary is not enough to resolve the problem of reduced motivation among healthcare workers (Bennell, 2004). Furthermore, it suggests that to motivate healthcare workers and nurture enhanced commitment to their career, healthcare institutions should place an emphasis on non-financial motivational factors - especially in view of the economic challenges threatening healthcare institutions and systems (Skefales et al., 2014). Therefore sustaining pay levels and consistent service related payments are essential for staff motivation and morale (McCoy et al., 2008), paying to improve performance is based on assumption that health workers need incentive schemes to perform (Hongoro \& Normand, 2006). However current evidence shows that changes in performance are not due to incentives alone, but a host of other factors like promotion, career development, training etc (Khim, 2016). Researchers on incentive schemes were un successful due to implementation obstacles and how to examine the total remuneration system, and gaps remain in the evidence about the effect of complex remuneration system on performance of health workers(Khim, 2016).

However, another research study piloted in Africa by (Mathauer \& Imhoff, 2006), stressed how nonfinancial factors motivated employees. This involved the platform for workers to continue in their 
professional development and career growth and development, as well as robust communication mechanisms that aim to strengthen employer-employee relationships and communication between coworker.

The available research data recommended that salary structures across nations and are often designed in complex ways. Health workers also commonly use other sources of income like agriculture, private clinics to supplement their formal pay (Bertone \& Witter, 2015). Salaries and revenues of health workers differs widely, whether between nations by comparison with the cost of living or between public and private sectors (McCoy et al., 2008).

Despite the analysis of the achievements and failures of health changes, in general, slight attention has been given to the human resources yet they play a significant part in determining the accomplishments of the health reforms in the entire country (Okuonzi, 2004). For prosperity and harmony, there is a need to adopt different organizational factors to improve health care services. This means that the executive arm of government and other officers in the Ministry of Health need to be informed about the organizational factors affecting the daily operations of health workers in Health Centres IV. Hence to cater for this need, the researcher sought to establish the association between organizational rewards and performance of Health workers in Health Centres IV in Greater Mbarara District.

The mid-term review (MTR) of the Health Sector strategic plan that took place in 2010, acknowledged poor workforce performance characterized by absenteeism, low productivity, negative attitudes towards patient care, rampant dualism and high turnover as major constraints to the achievement of the HSSP 11, (Health Sector Strategic Plan) whose overall objective was to obtain a good standard of health for all citizen in country (Uganda) for the mandate in promoting a good health care and productive life (Tashobya et al., 2016). The report recommended that Ministry of Health should develop a comprehensive health workforce motivation, and retention strategies for the health sector as a government initiative to improve their workers' performance. The strategies are fully formulated but are not yet fully implemented (Tashobya et al., 2016).

The labour force of Uganda over the previous decade have witnessed a number of industrial unrests particularly among public sector workers (Rwashana, Williams, \& Neema, 2009). For instance, in most of the years, health workers have laid down their tools, despite government refusing to cater for their demands (Kitanda, 2008). As a matter of fact, in the mid-2018, the government of Uganda threaten to employ Cuban doctors after a developing an impasse with health workers who were striking over rewards particularly salary increment (Rwashana et al., 2009). Due to this, health service delivery is faced by a series of factors limiting its employee performance, particularly stemming from meager salaries paid to health workers, unclear promotional strategies etc (Lewis, 2006).

However, there is scarcity of scientific evidence to ascertain the extent to which rewards for health workers influence their performance particularly in health centre IVs' which are in rural communities where the situation of health services is at its lowest (Rose, 2000). The objective of this study is to find out the relationship between organizational rewards and performance of health centre IV workers in Greater Mbarara District. 
More specific objectives are to find out;

To establish the relationship between Salary and performance of health centres IV workers.

To determine the relationship between Performance bonus and performance of health centres IV workers.

To establish the relationship between Recognition and performance of health centres IV workers.

To establish the relationship between Promotion and performance of health centres IV workers.

Based on the above objectives, the present study seeks to test the following hypothesis

$\mathrm{H}_{1}$ : There is a positive relationship between Salary and performance of health centres IV worker

$\mathrm{H}_{2}$ : There is a positive relationship between Performance bonus and performance of health centres IV workers

$\mathrm{H}_{3}$ : There is a positive relationship between Recognition and performance of health centres IV workers

$\mathrm{H}_{4}$ : There is a positive relationship between Promotion and performance of health centres IV workers

\section{Theoretical background and hypothesis development}

This study was set forth on Social exchange Theory (Blau, 1968). This theory proposes that the standards human beings use to assess costs and rewards vary over time and from individual to individual. Social exchange includes both a belief of association and some conception of a shared commitment in which both parties perceive responsibilities to each other.

Social exchange theory observes exchange as a social behaviour that may result both in economic and social outcomes. It also brings satisfaction when people obtain fair earnings for their expenditures (Cook, Cheshire, Rice, \& Nakagawa, 2013). This theory also weakens the power of social structures and forces, which unintentionally form our perception of the world and our experiences within it, and play a strong role in determining our relations with each other (S. Williams, 2001).

$H I$ Salary is positively related to performance of health centres IV workers.

\section{Salary and workers' performance}

Salaries /amount of salaries are extended to workers and can be well understood as a manner of enhancing performance among workers. This can well be explained in the role of money as a condition to strengthen, an incentive which is capable of satisfying needs, and anxiety reducer that serves to remove feelings of dissatisfaction (Richard, 2014). In the same spirit (Bassett-Jones \& Lloyd, 2005) report that two views of human nature underlay early research into employee motivation. The first view centres on Taylorism, which is seen people as mainly lazy and work-shy, and thus held that these set of workers can only improve their performance through external stimulation. The second view was based on Hawthorn findings, which held the sight that workers are motivated to work well for "its own sake" as well as for the social and monetary benefit. 
Some studies such as (Armstrong \& Stephens, 2005) contend that money is indeed a motivator and improves performance. This is because it can be perceived by individuals as a goal in itself; as a way of giving contentment to workers, and as a symbol of internal recognition or external status. Divergent studies have also discovered that salary is a poor motivator and can hardly influence the level of performance. It is further argued that it may yield temporary compliance rather than sustained enhancement. It does not amend behaviour, merely a superficial conformity with what the organization signals to be important. Workers' performance-related pay highlights individual contribution whereas the task might require teamwork; may cause short term effect on performance than long outcome on performance (Porter, Bigley, \& Steers, 2003).

$H 2$ Performance bonus is positively related to performance of health centres iv workers.

\section{Performance bonus and workers' performance}

Performance bonus refers to a payment system through which individual, group or performance is directly and monetarily compensated (Armstrong, 2010). (Boachie-Mensah \& Dogbe, 2011) suggested that performance-based pay is a structure that designed at compensating a worker centered on his/her performance. Performance incentive scheme is that of a base upon which individual worker and institutions rest (R. S. Williams, 2002). In as much as a worker acknowledges when, why and what is expected of him/her in terms of tasks, then the institutional goals are attainable and a worker feels being empowered (Ismail, Abdul-Majid, \& Joarder, 2015). Furthermore, performance-based pay is termed as a reward given to a worker within a compensation range that is competitive with that paid for similar work/tasks in different institutions. It is also based upon merit as empirically appraised in the firm's performance appraisal program, with a chance to receive above market pay for workers demonstrating extraordinary performance (Ismail et al., 2015).

Consequently, workers' performance is basically outcomes attained and accomplishments made at work. Performance refers to keeping up plans while aiming at the results. Although performance evaluation is the heart of performance management (Gruman \& Saks, 2011), the performance of an individual or an institution depends greatly on all institutional policies, practices, and design features of an institution. (Grant, 2008).

In recent time, institutions have believed in converting their reward system to performance-based pay system (Soeters, Habineza, \& Peerenboom, 2006). The basic drive of any performance-based reward system is to relate workers' salaries directly to their performance (Solmon \& Podgursky, 2000). Linking rewards to performance strengthens workers to increase their efficiency (Ismail et al., 2015). Performance-based reward system permits workers to a basic income and the chance to get extra reward if their outputs surpass the set performance standards (Kealesitse, 2009).

Robbins and Coulter (2007), argued that the social sciences have suggested many theories to investigate how payment raise that is linked to workers' performance might excite workforce to add more effort and set that effort on the achievement of organizational performance objectives. In contrast, some literature have shown less positive links between performance-based pay system and employee performance, while some studies have argued that implementation of performance-based pay system eventually builds a major obstacle in its success. It is not that workers do not like the system (Lavy, 2007) 
Boachie-Mensah and Dogbe (2011), added that poor implementation and poor management practices are the common impediments to performance-based initiatives. Performance-based pay system is considered less acceptable (Azman, Alimi, \& Rashidi, 2014). This is as of result being limited to one-dimensional monetary information. It had a reflective orientation, short-term vision, and a friable strategic content (Ismail et al., 2015).

H3 Recognition is positively related to performance of health centres IV workers.

\section{Recognition and workers' performance}

Recognition is the acknowledgement, gratitude, or endorsement of the positive happenings or behaviours of an individual or team (Tessema, Ready, \& Embaye, 2013). According to (Gostick \& Elton, 2009), recognition refers to praise or a personal note of acknowledging achievements including small gestures that are important to employees.

Gostick and Elton (2007) complete that if workers' recognition is conducted appropriately, it enhances productivity and customer service levels, and reinforce employee engagement and satisfaction. (Nelson, 2012) contemplates that recognition leads to improved communication (employees are more likely to propose solutions and new ideas), better cooperation (workers are more likely to propose to help and go the extra mile), and lessened absenteeism and turnover (workers will exhibit higher job satisfaction and loyalty).

Recognition ranks as one of the most powerful motivators and plays a key role in effective reward practices (Roberts, 2005). These unceremonious rewards entail minimal planning, efforts or expense (Gostick and Elton, 2007) and can be given for several reasons including recognition for a job well done, a birthday, a service anniversary, special favour, completing a disagreeable task, or saving the company time or money. Effective recognition procedures can also include verbal and written praise, public praise, and symbolic gestures by managers or line managers (Nelson \& Spritzer, 2002). Recognition efforts that are timely, sincere, and personal can serve as a major means of motivation to employees.

Also, (Nelson \& Spitzer, 2003) state that managers need to be in constant contact with the employees if they are to determine what they most value and then find ways to act systematically on those desired forms of recognition and rewards as they perform well. This suggests that managers need to vary the forms of recognition, adding new things, experimenting with them, and eliminating others that have run their course and are no longer motivating workers. If managers are timely, sincere, and specific in thanking employees when they have done good work it will maintain credibility in the recognition process.

Nelson (2005) further reveals that managers need to be specific and timely when providing recognition, which will help create positive feelings that will affect employee performance (Darling et al., 1997; Daniels, 1999). According to Gostick and Elton (2007), if employee recognition is to provide favourable outcomes, it needs to be applied within a context of goal-setting, open communication, trust and accountability. A good recognition program has to communicate attitudes and behaviours that are recognized by the organization

$H 4$ Promotion is positively related to performance of health centres IV workers. 
Promotion and workers' performance.

Effectiveness of promotions as a strategy for motivating and enhancing employee performance (Bohlander, Snell, \& Sherman, 2004) propagates that promotions involve a change of the assignment to that of a higher level in the organization. The new job normally provides an increase in pay and status and demands more skills and carries more responsibility. Promotions enable an organization to utilize the skills and abilities of its personnel more effectively thus, good performance is realized. The three principal criteria for determining promotions are merit, seniority, and potential (Beehr, Nair, Gudanowski, \& Such, 2004). Promotions, however, are sometimes constrained by the fact that many institutions do not follow these three principles (merit, seniority and potential). Often the problem is determining how much consideration to give to each factor. A common problem in organizations is that promotion primarily depends on past performance and seniority that sometimes leads to the promotion of employees to levels of their incompetence.

Therefore, promotions must be fair, based on merit and untainted by favouritism (Ddamulira Sseruyange, 2009). In some instances, even fair and appropriate promotions can create several problems. For instance, members of an organization who are bypassed feel resentful, which may affect their morale and productivity. In Uganda's context, there is always a problem of failure to retain staff especially higher cadres. This is evident in the most health facilities in the country due to brain drain. Similarly, (Ddamulira Sseruyange, 2009) contends that this problem has its roots in conditions of service and job satisfaction. There is no practical way to indicate that a man was impassioned outside the area of his/her competence without prejudice to his/her career, the up or out promotion policy ignores the possibility that a person may have the ability to perform with excellence in a lower grade job even though he may not have the ability for a higher grade job (Sukunala, 2016).

\section{Methodology}

\section{Design, Study Sites and Sample}

The study employed a cross-sectional survey design, where descriptive, correlational and explanatory approaches were used. In a cross-sectional study, a particular phenomenon is studied at a particular period of time. Cross-sectional designs are appropriate for studies designed at finding out the manifestation of a phenomenon, situation, problem or attitude, by identifying a cross-section of the population at a given time. Therefore, Cross-sectional research design is a form of observational study that investigates data collected from a population, or a representative subset, while correlational research design is a quantitative approach of research in which there are two or more variables from similar group of subjects from which a relationship can be determined if it happens or not (Mukyala, 2018).

\section{Study sites}


Greater Mbarara is composed of 4 districts; Mbarara, Ibanda, Isingiro and Karuhura which were created in 2005. The study population comprised of 11(Eleven) Health Centres IV in greater Mbarara District which include: Mbarara Municipal Health Centre IV, Bwizibwera Health Centre IV, Kinoni Health Centre IV, Bugamba Health Centre (Mbarara), Kabuyanda Health Centre IV, Nyamuyanja Health Centre IV, Rwekubo Health Centre IV, Rugaaga Health Centre IV (Isingiro), Ruhoko Health Centre IV (Ibanda), Kiruhura Health Centre IV and Kazo Health Centre IV. These were only designated health centre IVs in Greater Mbarara.

The study targeted population of health workers from 11 health Centre IVs in Greater Mbarara District. These health workers comprised of medical officers, clinical officers, nursing officers, laboratory attendants, non-medical staff and support staff. Since the study has a population of 409, Krejcie \& Morgan (1970) sample size selection model was employed to generate the study sample size. In this sample size of 200 participants were selected using both stratified and systematic sampling techniques.

Table 1: Sample distribution by category

\begin{tabular}{|l|l|l|}
\hline Population Category & Population size & Sample size \\
\hline Medical officers & 71 & 35 \\
\hline Clinical officers & 43 & 21 \\
\hline Nursing officers & 162 & 79 \\
\hline Medical laboratory attendants & 29 & 14 \\
\hline Non-medical staff & 38 & 19 \\
\hline Support staff & 66 & 32 \\
\hline Total & $\mathbf{4 0 9}$ & $\mathbf{2 0 0}$ \\
\hline
\end{tabular}

Source; (District Health Reports, 2019)

\section{Questionnaire and Measurement}

A semi-structured questionnaire was developed using item measures and scales developed and tested by previous scholars (Bhattacherjee, 2012); (Harris \& Brown, 2010) and (Churchill \& Iacobucci, 2004). The questionnaire comprised of mainly closed-ended questions and they were anchored on a five point Likert scale ranging from strongly disagree to strongly agree (05) to allow respondents register the degree of agreement. A pre-test of the instrument undertaken to establish the reliability and validity of the instrument before the main survey. It was self-administered by the researcher and his researcher assistants through interview approach and the exercise was carried out with in a period of three months to provide ample period to the completion of the questionnaire by the respondents. This was intended to achieve consistency and accuracy in answering the questions. Table. 2 shows variable and their measures reliability scale.

Table. 2 Variable and their Measurement. 


\begin{tabular}{|c|c|c|c|c|}
\hline $\begin{array}{l}\text { Global } \\
\text { Variable }\end{array}$ & Definition & $\begin{array}{l}\text { Dimensions and Issues } \\
\text { to examine }\end{array}$ & Measurement & Sample items \\
\hline \multirow[t]{3}{*}{$\begin{array}{l}\text { Organization } \\
\text { rewards }\end{array}$} & \multirow[t]{3}{*}{$\begin{array}{l}\text { the benefits, financial and } \\
\text { non-financial, that an } \\
\text { the employee obtains } \\
\text { through his/her } \\
\text { employment relationship } \\
\text { with an organization } \\
\text { (Malhotra et al., 2007) }\end{array}$} & $\begin{array}{l}\text { Salary } \\
\text { Evaluation of payment } \\
\text { received for the job } \\
\text { (Malhotra et al., 2007; } \\
\begin{array}{l}\text { Hackman \& Oldham, } \\
1974)\end{array}\end{array}$ & $\begin{array}{l}\text { Respondents' } \\
\text { mean score of } 4 \\
\text { items included in } \\
\text { the questionnaire } \\
\text { on a 5-point } \\
\text { scale. } \\
\text { *Very } \\
\text { unsatisfactory } \\
\text {....Very } \\
\text { satisfactory } \\
\text { *Very } \\
\text { unrewarding } \\
\text {...very } \\
\text { rewarding } \\
\text { *Very small } \\
\text {....very large } \\
\text { *Very wrong } \\
\text {....very right }\end{array}$ & $\begin{array}{l}\text { "The amount of salary I get at } \\
\text { this health facility is..." }\end{array}$ \\
\hline & & $\begin{array}{l}\text { Bonus \& Fringe benefits } \\
\text { Evaluation of bonus and } \\
\text { fringe benefits received } \\
\text { for the job (Malhotra et al., } \\
\text { 2007; Hackman \& } \\
\text { Oldham, 1974) }\end{array}$ & $\begin{array}{l}\text { Respondents' } \\
\text { mean score of } 4 \\
\text { items included in } \\
\text { the questionnaire } \\
\text { on a 5-point } \\
\text { scale. } \\
\text { *Very } \\
\text { unsatisfactory } \\
\text {...Very } \\
\text { satisfactory } \\
\text { *Very } \\
\text { unrewarding } \\
\text {....very } \\
\text { rewarding } \\
\text { *Very small } \\
\text {....very large } \\
\text { *Very wrong } \\
\text {....very right }\end{array}$ & $\begin{array}{l}\text { "The bonus and fringe } \\
\text { benefits I get at this health } \\
\text { facility is ...." }\end{array}$ \\
\hline & & $\begin{array}{l}\text { Promotion Evaluation of } \\
\text { promotion received for the } \\
\text { job (Malhotra et al., 2007; } \\
\text { Hackman \& Oldham, } \\
\text { 1974) }\end{array}$ & $\begin{array}{l}\text { Respondents' } \\
\text { mean score of } 4 \\
\text { items included in } \\
\text { the questionnaire } \\
\text { on a 5-point } \\
\text { scale. } \\
\text { *Very unjust } \\
\text {...Very just } \\
\text { *Very } \\
\text { unreliable....very } \\
\text { reliable }\end{array}$ & $\begin{array}{l}\text { "The promotion done at this } \\
\text { health facility is ...." }\end{array}$ \\
\hline
\end{tabular}




\begin{tabular}{|c|c|c|c|}
\hline & & $\begin{array}{l}\text { *Very negative } \\
\text {...very positive } \\
\text { *Very } \\
\text { unreasonable } \\
\text {....very } \\
\text { reasonable }\end{array}$ & \\
\hline & $\begin{array}{l}\text { Recognition Evaluation of } \\
\text { recognition received for } \\
\text { the job (Malhotra et al., } \\
\text { 2007; Hackman \& } \\
\text { Oldham, 1974) }\end{array}$ & $\begin{array}{l}\text { Respondents' } \\
\text { mean score of } 4 \\
\text { items included in } \\
\text { the questionnaire } \\
\text { on a 5-point } \\
\text { scale. } \\
\text { *Very unjust } \\
\text {...Very just } \\
\text { *Very } \\
\text { unreliable....very } \\
\text { reliable } \\
\text { *Very negative } \\
\text {...very positive } \\
\text { *Very } \\
\text { unreasonable } \\
\text {...very } \\
\text { reasonable }\end{array}$ & $\begin{array}{l}\text { "The recognition done at this } \\
\text { health facility is ...." }\end{array}$ \\
\hline $\begin{array}{l}\text { Workers' } \\
\text { performance }\end{array}$ & \begin{tabular}{l}
\multicolumn{3}{l}{ task performance or } \\
in-role job performance \\
(Motowidlo, \\
Williams \& Anderson, \\
1991)
\end{tabular} & $\begin{array}{l}\text { Respondents' } \\
\text { mean score on } 16 \\
\text { items included in } \\
\text { the questionnaire } \\
\text { on a 5-point } \\
\text { scale. } \\
1=\text { Never }(\mathrm{N}) 2= \\
\text { Rarely (R) } \\
3=\text { undecided (U), } \\
4=\text { Often }(\mathrm{O}) \\
5=\text { Always(A) }\end{array}$ & $\begin{array}{l}\text { "How frequent do you } \\
\text {...perform tasks that are } \\
\text { expected of you?" } \\
\text { Howfrequently do you ...meet } \\
\text { formal performance } \\
\text { requirements of the job? }\end{array}$ \\
\hline
\end{tabular}

\section{Data Processing and Analysis}

After the fieldwork, the data were entered into Statistical Package for Social Science (SPSS) version 21 and subjected to a thorough cleaning before hypothesis testing. Two statistical software packages were utilized to analyse the data collected. Specifically, SPSS version 21 was used for preliminary data analysis, while Analysis of Moments of Structures (AMOS) version 21 was used for Structural Equation Modelling (SEM) guided by confirmatory factor analysis.

\section{Ethical Approval}


The study was cleared by Mbarara University of Science and Technology Research Ethics Committee (under the Ref: MUREC 1/7) and informed consent was sought from the participants during data collection. The study was also approved by all the District Health Officers (Mbarara, Isingiro, Ibanda and Kiruhura) where the study sites are located.

\section{CFA Measurement model for Organizational Reward}

Fig. 1 CFA for Organisational rewards

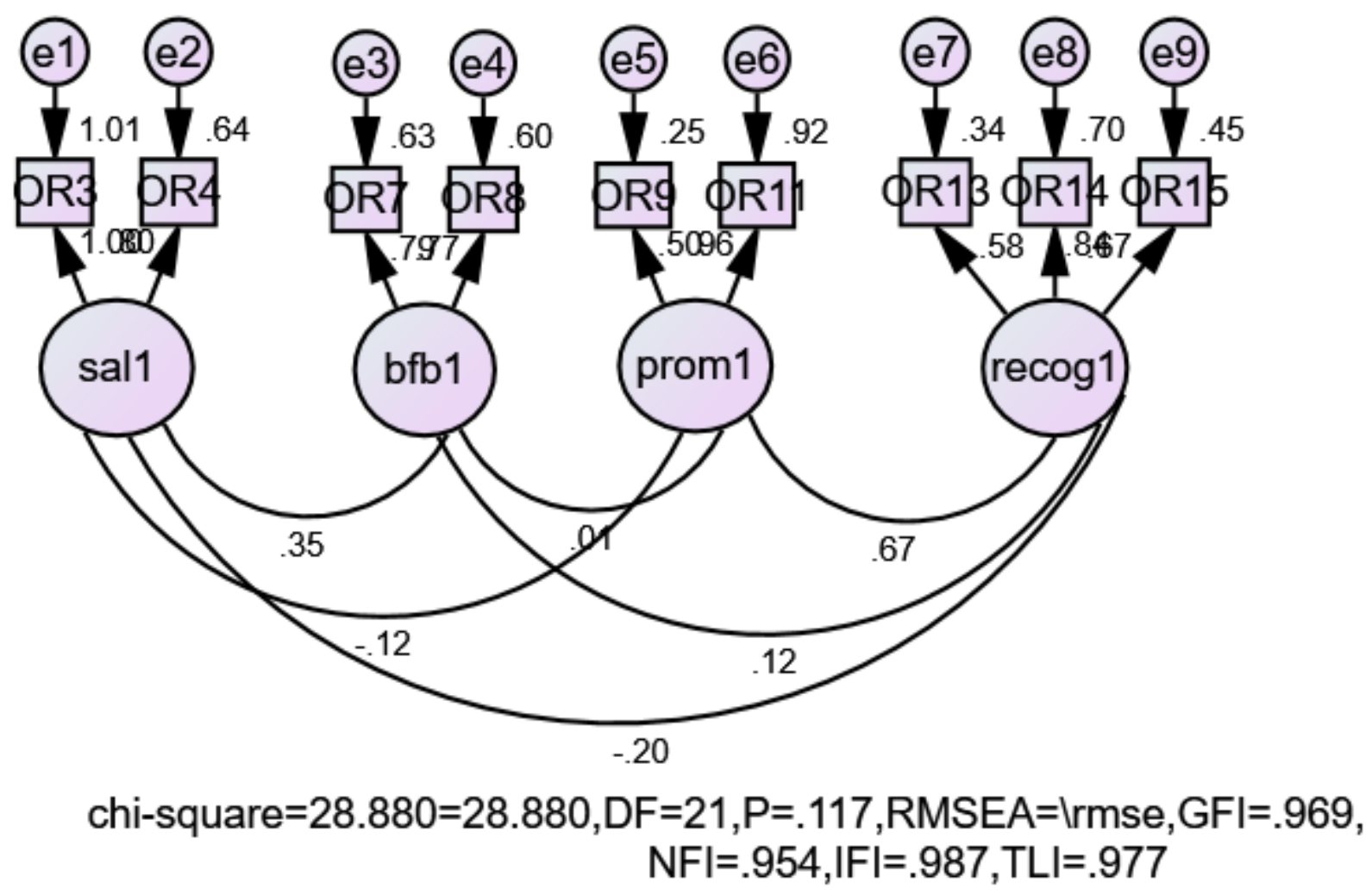

Organizational reward was measured using salary, bonus and fringe benefits, promotion and recognition. The results showed that although the standardized parameter estimates of the initial measurement model were all significant $(\mathrm{p}<.001)$, the model provided a poor fit as indicated by the poor fit-indices. The model was re-specified by iteratively removing five ('OR1' 'OR2', 'OR5', 'OR6', 'OR10' and 'OR16') out of fifteen items that did not meet the acceptable criteria. The removal of the weak correlated items did not change the content of the construct as it was conceptualized.

Table 3: Standardized weights for Organizational Rewards 


\begin{tabular}{|c|c|c|c|c|c|c|}
\hline Code & \multicolumn{3}{|l|}{ Items } & & $\begin{array}{l}\text { tandardi } \\
\text { egression } \\
\text { stimates }\end{array}$ & C.R $(\mathbf{t})$ \\
\hline & \multicolumn{6}{|c|}{ Salary - The amount of salary I get at this health facility is... } \\
\hline OR3 & \multicolumn{4}{|c|}{ Very small .....very large } & \multicolumn{2}{|l|}{0.92} \\
\hline \multirow[t]{2}{*}{ OR4 } & Very wrong ..... very & & & & 0.878 & \\
\hline & \multicolumn{6}{|c|}{ Bonus and fringe benefits - I get at this health facility is ... } \\
\hline OR7 & Very small .....very la & & & & 0.818 & \\
\hline \multirow[t]{2}{*}{ OR8 } & Very wrong ...... very & & & & 0.75 & \\
\hline & \multicolumn{6}{|c|}{ Promotion - done at this health facility is ... } \\
\hline OR9 & \multicolumn{4}{|c|}{ Very unjust ..... very just } & 0.512 & \\
\hline OR11 & \multicolumn{4}{|c|}{ Very negative .... very positive } & 0.862 & 8.47 \\
\hline \multirow[t]{2}{*}{ OR12 } & \multicolumn{4}{|c|}{ Very unreasonable .... very reasonable } & 0.622 & \\
\hline & \multicolumn{6}{|c|}{ Recognition -done at this health facility is ... } \\
\hline OR13 & Very unrealiable ..... & liable & & & 0.591 & 6.987 \\
\hline OR14 & Very negative .... very & & & & 0.83 & 8.439 \\
\hline OR15 & Very unreasonable ... & eason & & & 0.676 & \\
\hline \multicolumn{7}{|c|}{ Achieved Fit Indices } \\
\hline CMI & RMSEA & GFI & CFI & TLI & & NFI \\
\hline $\begin{array}{l}1.627 \\
\quad(52.0\end{array}$ & 63 / 32) & .954 & .970 & .957 & & 926 \\
\hline
\end{tabular}

The findings confirmed the validity of the final model with excellent model fit statistics for this construct measure as reported in table 3, even though the chi-square was still significant. The measurement model can be judged as providing an acceptable fit even though the chi-square value is statistically significant (Anderson \& Gerbing, 1988), especially with a large sample size (Bagozzi \& Yi, 1988). Other assumptions for convergent validity were also met. The composite reliability for organizational rewards is .798, which is within the acceptable level as indicated by Nunnally (1978).

\section{Results}

Descriptive statistics of the study variables

The descriptive statistics generated in this study included means and standard deviations. On a 5-point scale, the means for organizational reward and workers' performance are 3.205 and 3.361 with standard deviations of 0.5199 and 0.999 , respectively. According to Field (2009), when deviations are small compared to mean values, it is evident that the data points are close to the means, and hence, calculated means highly represent the observed data. 


\section{Correlation analysis}

The correlation results are presented in table 3.1. The results indicate a statistically strong significant relationship between organizational reward and performance of health Centre IV workers in greater Mbarara District $(\mathrm{r}=.474, p=.000)$. This provides support to hypothesis which states that there is a significant relationship between organizational reward and workers' performance among health Centre IV workers in greater Mbarara District. This means that positive changes in organizational reward are associated with positive changes in workers' performance. The results further show that hypotheses 1, 2, 3 and 4 which cover the relationship between the elements of organizational reward and workers' performance appear to be supported as well with salary having a stronger association followed by bonus and fringe benefits and for the case of promotion and recognition they have the same association with workers' performance

Table 3.1: Correlation results and descriptive statistics

\begin{tabular}{lllllll}
\hline Variables & $\mathbf{1}$ & $\mathbf{2}$ & $\mathbf{3}$ & $\mathbf{4}$ & $\mathbf{5}$ & $\mathbf{6}$ \\
\hline Salary(1) & 1 & & & & & \\
Bonus and fringe benefits(2) & $.283^{* *}$ & 1 & & & & \\
Promotion(3) & -.108 & .010 & 1 & & & \\
Recognition(4) & $-.170^{*}$ & .088 & $.503^{* *}$ & 1 & & \\
Organizational Rewards(5) & $.562^{* *}$ & $.600^{* *}$ & $.547^{* *}$ & $.551^{* *}$ & 1 & \\
Workers' Performance(6) & $.515^{* *}$ & $.169^{*}$ & $.145^{*}$ & $.145^{*}$ & $.474^{* *}$ & 1 \\
\hline
\end{tabular}

**. Correlation is significant at the 0.01 level (2-tailed). $n=198$ health workers

*. Correlation is significant at the 0.05 level (2-tailed).

The motivation of this study was driven by the possibility of differences in contribution of organizational rewards in explaining workers' performance. To do this, first, we regress organizational rewards as a global variable with the control variables (level of education of the health workers) on workers' performance. This is followed by a hierarchical regression where we determine the contribution of each element of organisational rewards in explaining workers' performance.

Regression analysis results for

Regression involving organizational factors as a global variable

Two models were specified as:

Model 1: $\mathrm{WP}=\mathrm{b}_{0}+\mathrm{b}_{1} \mathrm{E}+\varepsilon$

Model 2: $\mathrm{WP}=\mathrm{b}_{0}+\mathrm{b}_{1} \mathrm{E}+\mathrm{b}_{2} \mathrm{OR}+\varepsilon$

Where:

$W P=$ workers' performance

$b_{0}$ - is a constant

$b_{1} E$ - is the unstandardized $B$ coefficient of level of education of the health workers

$b_{2} O R$ - is the unstandardized B coefficient of organizational Rewards

$\varepsilon$ is the error term 


\section{Testing relationships between the elements of the Organization rewards and workers' performance}

Organizational rewards were conceptualized with three (3) factor variable (salary, bonuses and fringe benefits and promotion), the confirmatory factor analysis retained all the three indicators. The four factors were subjected to a regression analysis and the results are presented in table 4.2

Table 3.2: Regression of Organizational commitment (standardized coefficients)

\begin{tabular}{|c|c|c|c|c|}
\hline & Model 1 & Model 1 & Tol & VIF \\
\hline $\begin{array}{ll}\text { Level of } \\
\text { education }\end{array}$ & .030 & .027 & 1.000 & 1.000 \\
\hline Organizational I & Rewards & .474 & 1.000 & 1.000 \\
\hline \multicolumn{5}{|l|}{ Model summary } \\
\hline $\mathrm{R}^{2}$ & 0.001 & 0.225 & & \\
\hline $\operatorname{Adj} R^{2}$ & -0.004 & 0.217 & & \\
\hline $\mathrm{R}^{2}$ change & 0.001 & 0.224 & & \\
\hline F-stat & 0.176 & 56.419 & & \\
\hline Sig & 0.676 & .000 & & \\
\hline
\end{tabular}

In model 1, we regress the control variables (Level of education of the employees) on workers' performance and the results show that much as the variables explain $0.01 \%$ of the variance in workers' performance, their contribution effect is insignificant. Organizational rewards were added to the equation in model 2 , and the results indicated that Organizational rewards explain $22.4 \%$ of the variance in workers' performance. Overall, the model explains $21.7 \%$ of the variance in workers' performance. We also examine the variance inflation factors (VIFs) in our models to test for multi Collinearity. The highest VIFs were well below the threshold value of 10 suggested by Field (2009) indicating that multi Collinearity does not pose a problem to the regressions. However, the results do not tell us the particular element of Organizational rewards that has a greater effect. If we are to develop training packages to improve Organizational rewards and the consequent workers' performance, there is need to dissect Organizational rewards and identify the areas of emphasis. This led us to conduct a hierarchical regression analysis.

Regression involving the elements of organizational factors 
Four models were specified as:

Model 1: $\mathrm{WP}=\mathrm{b}_{0}+\mathrm{b}_{1} \mathrm{E}+\varepsilon$

Model 2: $\mathrm{WP}=\mathrm{b}_{0}+\mathrm{b}_{1} \mathrm{~A}+\mathrm{b}_{2} \mathrm{SS}+\varepsilon$

Model 3: $\mathrm{WP}=\mathrm{b}_{0}+\mathrm{b}_{1} \mathrm{~A}+\mathrm{b}_{2} \mathrm{~S}+\mathrm{b}_{3} \mathrm{BF}+\varepsilon$

Model 4: $\mathrm{WP}=\mathrm{b}_{0}+\mathrm{b}_{1} \mathrm{~A}+\mathrm{b}_{2} \mathrm{~S}+\mathrm{b}_{3} \mathrm{BF}+\mathrm{b}_{4} \mathrm{P}+\varepsilon$

Model 4: $\mathrm{WP}=\mathrm{b}_{0}+\mathrm{b}_{1} \mathrm{~A}+\mathrm{b}_{2} \mathrm{~S}+\mathrm{b}_{3} \mathrm{BF}+\mathrm{b}_{4} \mathrm{P}+\mathrm{b}_{4} \mathrm{R}+\varepsilon$

Where:

$W P=$ workers' performance

$b_{0}$ - is a constant

$b_{1} A-i$ s the unstandardised B coefficient of level of education of the health workers

$b_{3} S$ - is the unstandardized B coefficient of Salary

$b_{4} B F-i$ s the unstandardized $B$ coefficient of Bonuses and fringe benefits

$b_{5} P$ - is the unstandardized $B$ coefficient of Promotion

$b_{5} R$ - is the unstandardized B coefficient of Recognition

$\varepsilon$ is the error terme is the error term

Table 3.3: Hierarchical Regression Results

\begin{tabular}{|c|c|c|c|c|c|c|c|}
\hline & Model 1 & Model 2 & Model 3 & Model 4 & Model 5 & Tol & VIF \\
\hline $\begin{array}{l}\text { Level of } \\
\text { education }\end{array}$ & .030 & .002 & .001 & .027 & .016 & .973 & 1.028 \\
\hline Salary & & $0.514 * *$ & $0.507 * *$ & $0.531 * *$ & $.559 * *$ & .881 & 1.135 \\
\hline $\begin{array}{l}\text { Bonuses } \\
\text { and Fringe } \\
\text { benefits }\end{array}$ & - & & .025 & .015 & -.008 & .898 & 1.114 \\
\hline Promotion & & & & $0.205^{* *}$ & $.116^{*}$ & .730 & 1.370 \\
\hline Recognition & & & & & $.182 *$ & .715 & 1.399 \\
\hline \multicolumn{8}{|c|}{ Model summary } \\
\hline $\mathrm{R}^{2}$ & 0.001 & 0.265 & 0.265 & 0.306 & 0.33 & & \\
\hline $\operatorname{Adj} R^{2}$ & -0.004 & 0.257 & 0.254 & 0.292 & .313 & & \\
\hline $\mathrm{R}^{2}$ change & - & 0.264 & 0.001 & 0.041 & .024 & & \\
\hline F-stat & 0.176 & 69.985 & 0.155 & 11.419 & 6.831 & & \\
\hline Sig & 0.676 & .000 & 0.694 & 0.001 & 0.01 & & \\
\hline
\end{tabular}


The results in model 1 show that the control variable do not make a significant contribution in explaining adoption of workers' performance. This suggests that our models are not sensitive to confounding factors and the models are highly plausible. The addition of salary in model 2 reveals an extra contribution effect of $26.4 \%\left(\mathrm{R}^{2} \Delta=.264\right)$ in the variance explained workers' performance and the results indicate that salary is a significant predictor of workers' performance $(\beta=.559, \mathrm{p}=.000)$ implying that a unit increase in salary will result in to 0.559 units increase in workers' performance. The addition of bonuses and fringe benefits in model 3 accounts for the extra $0.01 \%\left(\mathrm{R}^{2} \Delta=.001\right)$ of the variance explained in workers' performance. The model results also show that bonuses and fringe benefits are not significant predictors of workers' performance $(\beta=-.008, \mathrm{p}>.05)$. The results in model 4 indicate that additional of promotion have significant effect on workers' performance and it explains $4.1 \%\left(\mathrm{R}^{2} \Delta=.041\right)$ of the variations in the workers' performance and the results indicate that a unit increase in promotion of the workers would result in to 0.116 units increase in workers' performance $(\beta=-.008, \mathrm{p}<.001)$. Finally, the results in model 5 indicate that recognition of the workers explain $2.4 \%\left(\mathrm{R}^{2} \Delta=.024\right)$ and a unit increase in recognition of the workers would result in to 0.182 units increase in workers' performance $(\beta=.182, \mathrm{p}=.000)$. When predictive power and strength of all the four elements are compared, salary has a greater effect on workers' performance. The results also validate hypotheses $1,2,3 \& 4$. Overall, the model explains $31.1 \%$ of the variance in workers' performance. The remaining $68.9 \%$ is catered for by factors not covered in this study.

\section{Discussion}

The results show that organizational rewards and workers' performance are positively related, and the association is statistically significant $(\mathrm{r}=.474, p=.000)$, thus the stated hypothesis is accepted. This indicates that positive changes in organizational rewards are associated with positive changes in health centre IV workers. This was supported by (Chiang \& Birtch, 2008) who found that the absence of rewards will create an unfriendly environment, thus weakening workers and may cause them to pull out of their jobs. For these reasons, rewards are progressively important because they appeal, maintain and motivate employees to achieve high levels of performance and to stimulate and strengthen the desired behaviour of the workers. Organizations often use financial rewards to avoid employee disappointment and to motivate employees, although it may not be the best motivator for the long term (Mossbarger \& Eddington, 2003).

The results show that all the respondents agree that salary influences their commitment and performance. This was in agreement with (Dorling, 2019) who argued that employees who receive a good pay are likely to be dedicated to the health facilities simply because they would not afford to lose the big salaries. That is why health workers have been involved in strikes or sit down strikes and engaging government in different fora to improve their remunerations. This is an indication that if the government has to deal with health workers grievances of remunerations, focus should be premised on salary other than fringe benefits, promotion and recognition. This shows that in an event that a health worker receives adequate salary, there are higher chances that he/she will be committed and will perform better in the absence of other work related benefits. 
This was in agreement with Richard (2014) who stated that salaries /amount of salaries given to employees can be well understood as a way of improving performance among employees. This can well be explained in the role of money as a condition to reinforce, an incentive which is capable of satisfying needs, and anxiety reducer that serves to erase feelings of dissatisfaction among employees.

On contrary, some studies (Pandey, 2020),urges that although salary is acknowledged by employees, managers should never use this as a tool to motivate their employees and improve on the performance. Should this occur, there is a transformation that the core principle of the reward would be forgotten. However, the above findings indicate that bonus, fringe benefits and promotion do not play a significant role as far as the health workers performance is concerned. This was also supported by (Magesa \& Leshabari, 2017), who noted that assessment of performance-based financing (PBF) plans in a few settings found bonus payments to be demotivating in cases where the distribution is not transparent, perceived inequitable and perceived unfairness in distribution of resources and decision-making process create no impact on the performance of health workers.

Majority of the respondents supported the idea salary improves performance, they said that the salary enhancement that took place in the country especially for scientists, helped them to improve on their performance though the salary is still not commensurate. This was supported by (Richard, 2014) who elucidated on the role money as a condition to strengthen an incentive which is capable of satisfying employees' needs and anxiety so as to remove feelings of dissatisfaction so as enhance on the productivity and employee availability.

Majority of respondents supported giving bonus and recognition as a form of reward. This would come as result of performing their duties in time, responding to emergencies in time, attending to patients and be quick at delivering health services from their respective health facilities. This was in agreement with (WillisShattuck et al.,2008) who show some seriousness in valuing the workers by providing monetary and nonmonetary rewards which consisted of recognition and cash bonuses to workers and these are given separately from the salary and should be fairly allocated based on their performances so as to continue with improved productivity.

\section{Research limitations}

This study focuses on rewards, and performance of health workers' in health centres iv in greater Mbarara and it is possible that these results are only applicable to the public health centres iv in greater Mbarara

We therefore highlighted two limitations for this study: First, the study was limited to health centre IVs in greater Mbarara district and it is possible that the results may only be generalized to health sector not only in Uganda but also in other communities of the world. Secondly, we majorly focused on health centres IV workers and their performance, we suggest that further research could be carried out in other levels of health care system in Uganda like; private health sector, health centres ii, iii, hospitals and regional referral facilities respectively using the same methodology or even using mixed methods.

\section{Conclusions and Recommendations}


The purpose of this study was to find out the relationship between salary and performance of health workers' in greater Mbarara district. This was achieved through a questionnaire survey of 200 health workers in health centres IV representing $98 \%$ response rate. Results indicate that rewards are significant predictor of health workers' performance.

Overall findings of this study have important implications to both academics, practitioners and government. For academics, the results suggested salary is strong predictor of health workers' performance in health centres IV in greater Mbarara district. For health practitioners, they should recognize different remuneration strategies that influence performance positively like; bonus, merit pay and good salary policy. Also they should consider other non-financial rewards like recognition, promotion and career development programs for their health workers.

For government, the findings are important, when it comes to budgeting, planning and spending, it should aim at meeting health workers' needs and desires so as to reduce on labour turnover in the health sector. 


\section{LIST OF ABBREVIATIONS}

$\begin{array}{ll}\text { AMOS } & \text { Analysis of Moments of Structures } \\ \text { CFA } & \text { Confirmatory Factor Analysis } \\ \text { CFI } & \text { Comparative Fit Index } \\ \text { GFI } & \text { Goodness of Fit Index } \\ \text { HSSP } & \text { Health Sector Strategic Plan } \\ \text { MTR } & \text { Mid-Term Review } \\ \text { PBF } & \text { Performance Based Training } \\ \text { RMSEA- } & \text { Root Mean Square Approximation } \\ \text { MUST-REC } & \text { Mbarara University of Science and Technology Research Ethics Committee } \\ \text { NFI } & \text { Normed Chi-square Index } \\ \text { SEM } & \text { Structural Equation Modeling } \\ \text { SPSS } & \text { Statistical Packages for Social Scientists } \\ \text { TLI } & \text { Tucker Lewis Index } \\ \text { UK } & \text { United Kingdom } \\ \text { VIF } & \text { Variance Inflation Factor } \\ & \end{array}$

\section{Declaration}

\section{Ethical approval and consent to participants}

The study was approved by the Mbarara University Research Ethics committee (MUREC-1/7: 17/9-19). Permission to conduct interviews in the HCs was obtained from the District Health Officers (DHOs) where the study sites are located-Kiruhura, Ibanda, Mbarara, and Isingiro distircts. All participants provided voluntary written informed consent before each in-depth interview or questionnaire was administered. Privacy of the participants was ensured by not including identifiable information in addition to conducting the interviews in private. We respected individual autonomy to participate in the study as eligible participants were free to decline to participate; all who consented to participate were informed about 
their freedom to withdraw from the study at any time. No participant withdrew from the study. All the audio recorded material and transcripts were safely stored by to the lead author Johnson Atwiine

\section{Consent to publication}

Not Applicable

\section{Availability of supporting data}

Data on which this manuscript is based will not be publicly available since this work is still ongoing but will be available in future when the Ph.D. program is completed.

\section{Competing interests}

The authors declare that they have no competing interests.

\section{Funding}

This study did not receive any funding.

Authors' contributions

JA developed the questionnaire tool in consultation GA, WT, and JAs; JA interviewed the research assistants who were then trained by JAs and WT; JA checked the filled questionnaires before handing them to data analyst for data cleaning and analysis. Data Analysis and interpretation was checked by AJ and JAs. All authors contributed to the final product. All authors read and approved the final manuscript.

\section{Acknowledgements}

We recognize the great work done by Benjamin Musiita and Sedrack Atuhaire our research assistants; this work would not have been completed without your dedication to the data collection.

\section{Authors details}

${ }^{a}$ Department of Economics, Statistics \& Tourism Management, Bishop Stuart University, Mbarara

${ }^{b}$ Faculty of Business, Economics and Governance, Bishop Stuart University-Mbarara 
${ }^{c}$ Applied Science and Technological Innovations, Bishop Stuart University-Mbarara

${ }^{d}$ Department of Community Engagement and Service Learning, Faculty of Interdisciplinary studies, Mbarara University of Science and Technology.

\section{References}

Adzei, F. A., \& Atinga, R. A. (2012). Motivation and retention of health workers in Ghana's district hospitals. Journal of health organization and management.

Armstrong, M. (2010). Armstrong's handbook of reward management practice: Improving performance through reward: Kogan Page Publishers.

Armstrong, M., \& Stephens, T. (2005). A handbook of employee reward management and practice: Kogan Page Publishers.

Azman, I., Alimi, A., \& Rashidi, A. (2014). Effect of manager's role in performance based pay on employee outcomes. Global Journal Al-Thaqafah, 4(2), 41-58.

Bassett-Jones, N., \& Lloyd, G. C. (2005). Does Herzberg's motivation theory have staying power? Journal of Management Development, 24(10), 929-943.

Beehr, T. A., Nair, V. N., Gudanowski, D. M., \& Such, M. (2004). Perceptions of reasons for promotion of self and others. Human Relations, 57(4), 413-438.

Bennell, P. (2004). Teacher motivation and incentives in sub-Saharan Africa and Asia. Knowledge and Skills for development, Brighton.

Bertone, M. P., \& Witter, S. (2015). The complex remuneration of human resources for health in low-income settings: policy implications and a research agenda for designing effective financial incentives. Human resources for health, 13(1), 62.

Bhattacherjee, A. (2012). Social science research: Principles, methods, and practices.

Blau, P. M. (1968). Social exchange. International encyclopedia of the social sciences, 7, 452-457.

Boachie-Mensah, F., \& Dogbe, O. D. (2011). Performance-based pay as a motivational tool for achieving organisational performance: An exploratory case study. International Journal of Business and Management, 6(12), 270-285.

Bohlander, G., Snell, S., \& Sherman, A. (2004). Managing human resources Mason. OH: Thomson/South-Western.

Chiang, F. F., \& Birtch, T. A. (2008). Achieving task and extra-task-related behaviors: A case of gender and position differences in the perceived role of rewards in the hotel industry. International Journal of Hospitality Management, 27(4), 491-503.

Churchill, G., \& lacobucci, D. (2004). Marketing research: Methodological foundations Thomson Corporation. South Western, Ohio.

Cook, K. S., Cheshire, C., Rice, E. R., \& Nakagawa, S. (2013). Social exchange theory Handbook of social psychology (pp. 61-88): Springer.

Ddamulira Sseruyange, C. (2009). Promotions as a motivation factor towards employees' performance: a case study of Uganda police forces (UPF)(1995-2005). Makerere University.

Dieleman, M., Cuong, P. V., \& Martineau, T. (2003). Identifying factors for job motivation of rural health workers in North Viet Nam. Human resources for health, 1(1), 10.

Dieleman, M., \& Harnmeijer, J. W. (2006). Improving health worker performance: in search of promising practices. Geneva: World Health Organization, 5-34.

Dorling, D. (2019). Inequality and the 1\%: Verso. 
Gostick, A., \& Elton, C. (2009). The Carrot Principle: How the Best Managers Use Recognition to Engage Their People, Retain Talent, and Accelerate Performance [Updated \& Revised]: Simon and Schuster.

Grant, A. M. (2008). The significance of task significance: Job performance effects, relational mechanisms, and boundary conditions. Journal of applied psychology, 93(1), 108.

Gruman, J. A., \& Saks, A. M. (2011). Performance management and employee engagement. Human Resource Management Review, 21(2), 123-136.

Harris, L. R., \& Brown, G. T. (2010). Mixing interview and questionnaire methods: Practical problems in aligning data.

Hongoro, C., \& Normand, C. (2006). Health workers: building and motivating the workforce. Disease control priorities in developing countries, 2, 22.

Ismail, A. I., Abdul-Majid, A.-H., \& Joarder, M.-H. (2015). Pay-performance relationship: An empirical study on employee performance in the context of Nigeria. ADVANCES IN GLOBAL BUSINESS RESEARCH Vol. 12, No. 1, ISSN: 1549-9332, 782.

Kealesitse, B. (2009). The impact of performance-based reward system (PBRS) on customers' perceived service outcomes. Victoria University.

Khim, K. (2016). Are health workers motivated by income? Job motivation of Cambodian primary health workers implementing performance-based financing. Global health action, 9(1), 31068.

Kitanda, J. (2008). workload-based indicators of staffing need (WISN) for health tutors in two public health training institutions in uganda.

Lavy, V. (2007). Using performance-based pay to improve the quality of teachers. The future of children, 87-109.

Lewis, M. (2006). Governance and corruption in public health care systems. Center for Global Development working paper(78).

Magesa, D. J., \& Leshabari, M. (2017). Perceived barriers to access available health services among men who have sex with men in Dar es Salaam, Tanzania. Tanzania Journal of Health Research, 19(4).

Mathauer, I., \& Imhoff, I. (2006). Health worker motivation in Africa: the role of non-financial incentives and human resource management tools. Human resources for health, 4(1), 24.

McCoy, D., Bennett, S., Witter, S., Pond, B., Baker, B., Gow, J., . . McPake, B. (2008). Salaries and incomes of health workers in sub-Saharan Africa. The Lancet, 371(9613), 675-681.

Mossbarger, M., \& Eddington, J. (2003). Methods for motivating employees. Weber State University.

Mukyala, B. (2018). Factors Affecting Timing Of 1st Antenatal Care Among Mothers At Antenatal Clinic In Bukigai Health Centre lii Bududa District. International Health Sciences University.

Neckermann, S., \& Kosfeld, M. (2008). Working for Nothing? The Effect of Non-Material Awards on Employee Performance. SSRN eLibrary.

Nelson, B. (2012). 1501 ways to reward employees: Workman Publishing.

Nelson, B., \& Spitzer, D. R. (2003). The 1001 rewards \& recognition fieldbook: the complete guide: Workman Publishing.

Okuonzi, S. A. (2004). Learning from failed health reform in Uganda. BMJ: British Medical Journal, 329(7475), 1173.

Pandey, N. (2020). Critical Evaluation of Most Valued Non-Monetary Rewards Employees. Our Heritage, 68(30), 8718-8728.

Porter, L. W., Bigley, G. A., \& Steers, R. M. (2003). Motivation and work behavior.

Qureshi, M. I., Zaman, K., \& Shah, I. A. (2010). Relationship between rewards and employee's performance in the cement industry in Pakistan. Journal of international academic research, 10(2), 19-29.

Richard, B. (2014). The Effect Of Motivation On Employees 'performance: Empirical Evidence From The Brong Ahafo Education Directorate. Kwame Nkrumah University, 19.

Robbins, S. P., \& Coulter, M. (2007). Principles of management. Translated by Seyyed Mohammad Arabi and Mohammed Ali Hamid Rafiee and Behrouz Asrari Ershad, Fourth Edition, Tehran: Office of Cultural Studies.

Roberts, R. L. (2005). The relationship between rewards, recognition and motivation at an Insurance Company in the Western Cape. University Of The Western Cape. 
Rose, R. (2000). How much does social capital add to individual health? Social science \& medicine, 51(9), 14211435.

Rwashana, A. S., Williams, D. W., \& Neema, S. (2009). System dynamics approach to immunization healthcare issues in developing countries: a case study of Uganda. Health Informatics Journal, 15(2), 95-107.

Skefales, A., Plakas, S., Fouka, G., Goni, M., Vassiliadou, M., \& Bergiannaki, J.-D. (2014). Burnout and its association with working conditions among Greek hospital nurses in a time of financial crisis. Open Journal of Nursing, 2014.

Soeters, R., Habineza, C., \& Peerenboom, P. B. (2006). Performance-based financing and changing the district health system: experience from Rwanda. Bulletin of the World Health Organization, 84, 884-889.

Solmon, L. C., \& Podgursky, M. (2000). The Pros and Cons of Performance-Based Compensation.

Sukunala, E. (2016). An Analysis of Employee's Perception on Motivation Mechanism in Public Service: Empirical Evidence from Katavi Police Force. The Open University of Tanzania.

Tashobya, C. K., Dubourg, D., Ssengooba, F., Speybroeck, N., Macq, J., \& Criel, B. (2016). A comparison of hierarchical cluster analysis and league table rankings as methods for analysis and presentation of district health system performance data in Uganda. Health policy and planning, 31(2), 217-228.

Tessema, M. T., Ready, K. J., \& Embaye, A. B. (2013). The effects of employee recognition, pay, and benefits on job satisfaction: cross country evidence. Journal of Business and Economics, 4(1), 1-12.

Williams, R. S. (2002). Managing employee performance: Design and implementation in organizations: Cengage Learning EMEA.

Williams, S. (2001). Emotion and social theory: corporeal reflections on the (ir) rational: Sage. 
Figures

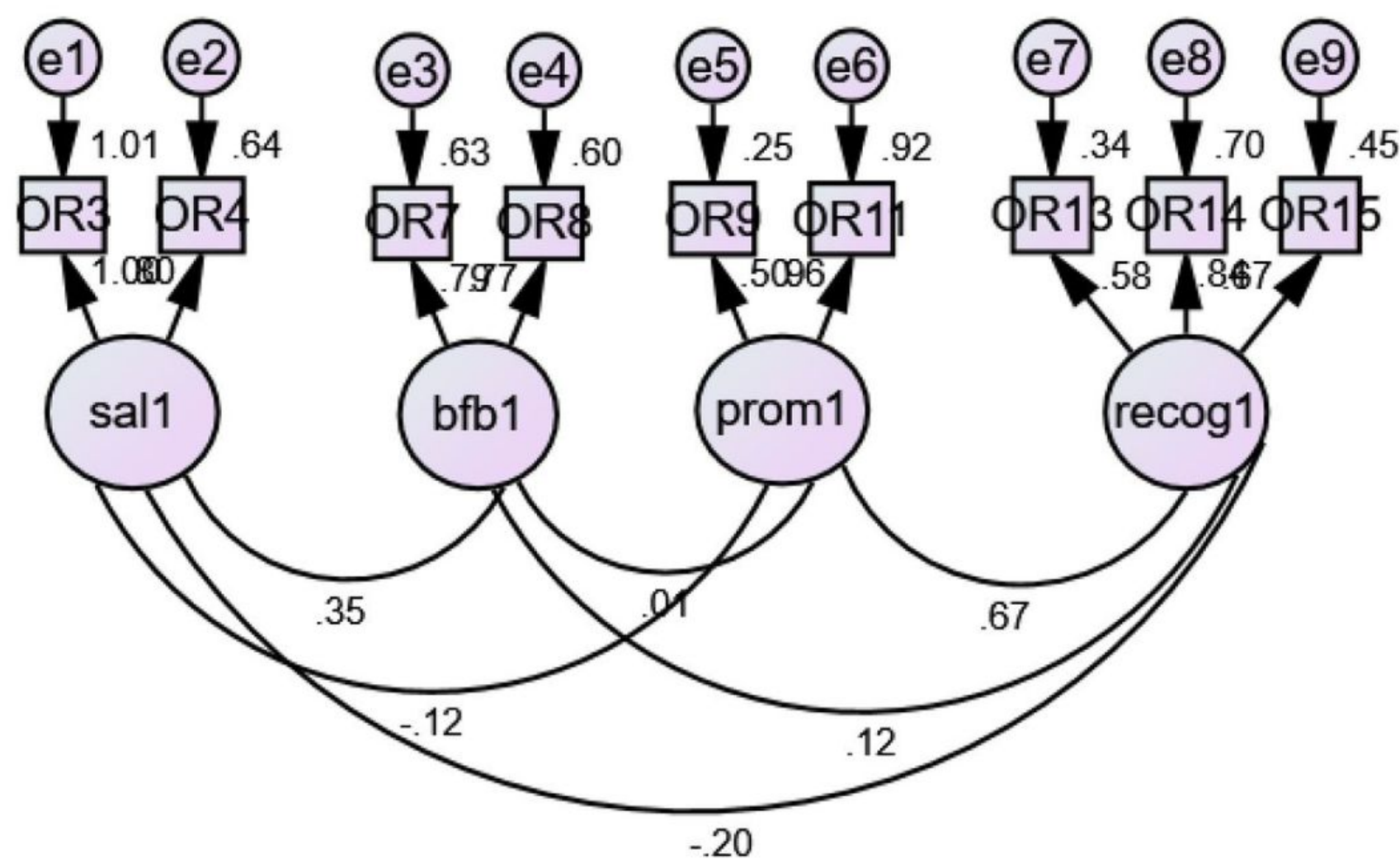

chi-square $=28.880=28.880, \mathrm{DF}=21, \mathrm{P}=.117, \mathrm{RMSEA}=\mid \mathrm{rmse}, \mathrm{GFI}=.969$, $\mathrm{NFI}=.954, \mathrm{IFI}=.987, \mathrm{TLI}=.977$

Figure 1

CFA for Organisational rewards 